City University of New York (CUNY)

CUNY Academic Works

Publications and Research

Graduate Center

2001

\title{
On the Grounds of Globalization: A Topography for Feminist Political Engagement
}

Cindi Katz

CUNY Graduate Center

\section{How does access to this work benefit you? Let us know!}

Follow this and additional works at: http://academicworks.cuny.edu/gc_pubs

Part of the Feminist Philosophy Commons, and the Political Economy Commons

\section{Recommended Citation}

Katz, Cindi, "On the Grounds of Globalization: A Topography for Feminist Political Engagement" (2001). CUNY Academic Works. http://academicworks.cuny.edu/gc_pubs/302

This Article is brought to you by CUNY Academic Works. It has been accepted for inclusion in Publications and Research by an authorized administrator of CUNY Academic Works. For more information, please contact AcademicWorks@gc.cuny.edu. 


\title{
On the Grounds of Globalization: A Topography for Feminist Political Engagement
}

\author{
How lifeless all history is without topography.
}

-John Hill Burton 1864, The Scot Abroad

lobalization is nothing new. Global trade has been going on for millennia - though what constitutes the "globe" has expanded dramatically in that time. And trade is nothing if not cultural exchange, the narrow distinctions between the economic and the cultural having long been rendered obsolete. Moreover, our forbears, like us, were great "miscegenators." If here I gloss the racialized and gendered violence often associated with miscegenation, I do so strategically to note that all recourse to purity, indigeneity, or aboriginality - however useful strategically - should be subject to at least as much scrutiny as the easy romance with hybridity (see Mitchell 1997). Globalization has been the signature dish of capitalism - a system of social relations of production and reproduction nourished by uneven development across a range of spatial scales, from the local or regional to the national or supranational, the ambitions of which have always been global - since its birth in Europe more than five centuries ago. European-born mercantile capitalism early on was driven by a real expansion for markets and the goods to trade across them. This was nothing new, particularly, until the agents of capital began to assemble an empire and deployed the physical and symbolic violence intended to redirect toward European interests the globe Europeans were "discovering." With

Thanks to Gill Hart for inviting me to participate in a panel on "topographies of race and gender" at the Gender and Globalization Conference at University of California, Berkeley, in March 1998. The presentations and comments of Gill and other participants in that conference were invaluable and inspiring. Versions of this article were presented at "Global Gender Politics: A Cross Disciplinary Conversation," sponsored by Florida International University in March 1999, and at the Women's Studies Colloquium at Johns Hopkins University in March 2000, and I am grateful to participants at these events for their insights, questions, and suggestions. Thanks especially to Richa Nagar, Neil Smith, and two anonymous reviewers for their generous and insightful readings of the manuscript. The 1995 research in Sudan was funded by a faculty research award from the Professional Staff Congress of the City University of New York. I am grateful for their support of my work. 
colonization and other imperial acts, Europeans of the ascendant capitalist class began to disrupt and rework ongoing material social practices and relations of production and exchange in other parts of the world in order to direct capital accumulation their way. Globalization, of course, is just another way of saying (and doing) imperialism, and since, worldwide, we are living in the shards of a Eurocentric but global capitalism, it behooves us to understand its work in the world, including the searing unevenness of capital's investments and disinvestments, the social costs of the privatization of public life, and the excruciating predations of all manner of state violence.

Part of that project might be to track and capture the terminology itself-why the shift to talk of globalization these past few years? Many people have done this work quite effectively, demonstrating the links between the rise of the term and the stepped-up mobility of capital and labor, decolonization, and the need to reinforce everyday that "we" indeed are the world against fractious irruptions of nationalism and self-determination that at once refuse the bait and are its monstrous catch. It is more interesting to me to examine the intersecting effects and material consequences of so-called globalization in a particular place, not to valorize either experience or the local, but, quite the opposite, to reveal a local that is constitutively global but whose engagements with various global imperatives are the material forms and practices of situated knowledge. Examining these effects and practices as such is a means to develop a politics that works the grounds of and between multiply situated social actors in a range of geographical locations who are at once bound and rent by the diverse forces of globalization. That is where topography comes in.

What is a topography? "Topography," according to the Oxford English Dictionary (OED) (1971), is "the accurate and detailed delineation and description of any locality." But there is an ambiguity there because topography is also "the features of a region or locality collectively." The thing itself as much as the description of it are produced, and unraveling the processes of how they came to be can reveal the powerful interests vested in topography and topographical knowledge. The OED notes that in The Holy State. The Profane State, written in 1642, Thomas Fuller distinguished between "cosmography, treating of the world in whole joynts"; "chorography, shredding it into countries"; and "topography, mincing it into particular places" (75). Indeed, there is a long tradition in geography going back at least to the ancient geographer Strabo who developed the notion of "chorology" or "chorography" that has pursued just this sort of specialized study of particular places or regions. As Michel Foucault made vivid, such "mincing" and "shredding" by the forces of dominance are disciplining practices. 
This work, which persists to this day within and outside of geographycertain variants of area studies are but one of its contemporary forms was purposive, partial, and, of course, interested, and it was usually conducted for political leaders or military commanders. Not much has changed. Topographical data are routinely fed to any number of global databases using much touted geographical information systems (GIS) that facilitate resource extraction, surveillance, and rule and, if necessary, attack across geographic scale by various social actors. People in power seem to have gone map-crazy, which at times seems no more than a form of "gun-crazy" once removed.

These practices suggest the integumentary nature of topographical knowledge to the imperial practices glossed as globalization, as well as to more down-home forms of domination and exploitation. The New York City Police Department, for instance, has intricate maps of neighborhood crime, except that white-collar crime is omitted by definition; mappings of the socioeconomic and demographic particulars of each zip code have enabled targeted marketing by telephone, fax, mail, and electronic ether. Local and regional knowledge, the kind produced as topographies, facilitates global (and other forms of) rule. If topographical knowledge is so integrally important to capitalists and other agents of domination and to the maintenance of uneven development, its appropriation should be important to countering them.

What I want to offer here is a noninnocent topography of globalization and its entailments in one place as a vehicle for developing a gendered oppositional politics that moves across scale and space. The place in question is in central eastern Sudan, a village that I call Howa, where I have worked, and sometimes lived, since 1980. In producing this topography, I have no intention of offering "the local" as a bulwark against "the global," or as an instance of something more true, real, or differentiated in a rapidly homogenizing world. Homogenization is not the script of globalization so much as differentiation and even fragmentation. In fact, while globalization may be nothing new, what is new, suggests Michel-Rolph Trouillot (1996), is the greater awareness of global processes among increasingly fragmented populations all over the world. Given the growth and velocity of what he calls "global flows," Trouillot indicates that this awareness of globality is increasing everywhere (1996). While contemporary globalization may be understood as people, capital, and information moving with greater density, faster and further, it is also through these means that globality comes home and reworks that too. Much like Inderpal Grewal's and Caren Kaplan's (1994) "scattered hegemonies," Trouillot calls this phenomenon "fragmented globality," and he suggests that world histories (and geographies) 
and local histories (and geographies) are simultaneously becoming more intertwined and more contradictory (1996).

These contradictions are increasingly ugly. Thus, without romanticizing the local scale or any particular place, I want to get at the specific ways globalization works on particular grounds in order to work out a situated, but at the same time scale-jumping and geography-crossing, political response to it (see Smith 1992). Tracing the contour lines of such a "countertopography" to other sites might encourage and enable the formation of new political-economic alliances that transcend both place and identity and foster a more effective cultural politics to counter the imperial, patriarchal, and racist integument of globalization.

The particular grounds in question are those of Howa in central eastern Sudan. The village was settled by pastoralists in the late nineteenth century. According to local residents, Howa was established in the 1870s about twelve years before the period of national rule known as the Mabdiyya, which was brought about in 1885, when the forces of Muhammed Ahmad al-Mahdi overthrew Ottoman rule and was ended by the reconquest in 1898, when British forces led by Kitchener defeated the independent state and established the Anglo-Egyptian Condominium. The village was located on the Dinder River, an ephemeral stream that provided year-round access to water, in an area of woodland savannah and clay soils. There was enough rainfall to support the cultivation of sorghum and a few other crops, but animals remained an important part of the village economy and people's everyday lives. People in Howa kept close economic and social ties with their still nomadic kin throughout the twentieth century, sharing family celebrations and extended visits, having livestock graze seasonally with the flocks of their nomadic relatives, and sometimes intermarrying.

From the time of its settlement until the end of the 1960s, Howa was characterized by a largely subsistence economy built upon a mixture of land use practices that included dryland cultivation of the staple food crop, sorghum, sesame grown for cash, animal husbandry, and forestry. Villagers provided for their own subsistence through the cultivation of sorghum and a small number of other crops, the production of milk and other dairy products, and the occasional sharing of an animal for meat. They cut wood for fuel, construction, and furniture from the surrounding savannah forests, and they gathered various fruits, nuts, medicines, and other resources from the woodlands as well. Their relatively minimal needs for cash (for taxes imposed by the colonial government and for selected goods such as tea, coffee, sugar, cloth, and tobacco) were met by selling sesame to merchants who passed through the area at harvest time, the occasional sale of an animal trekked most commonly to El Guesi (Dinder), twenty-five 
kilometers away, and the sale of surplus sorghum. Of course, some of the local population were more involved in the cash economy early on. Some were petty traders; some were religious Shaykhs receiving tributes from followers and providing amulets, blessings, advice, and the like in exchange for a small fee; some were moneylenders or involved in (illegal) crop mortgage schemes; some were tenants in private pump schemes established in the 1950s to grow cotton along the Blue Nile; and some, of course, were all of the above. Few worked as wage laborers seasonally or otherwise through the first half of the twentieth century. Most households were able to make do with a varying mix of cultivation, animal husbandry, and forestry, and virtually all of the young people coming of age in the village stayed there when they formed households of their own.

The land tenure system, as in much of central Sudan, was a patchwork of small holdings held in common and distributed as needed by the local Shaykh. Most farm households cultivated more than one small plot to mitigate the effects of crop pests, poor rains, drainage problems, and the like. Rain-fed land was cultivated for as long as twenty years before it was left fallow and new land cleared. Young men coming of age were allocated land from family holdings, fallow areas, or common lands. The only constraint on access to cultivable land was distance from the village, and, by the time the system was undone by the coming of a state-sponsored agricultural project, all plots were less than an hour's walk away. Villagers had access to wood and grazing resources in their holdings, in fallowed fields, and in the common land and waste areas around the village. Various accounts of land use in the area just prior to its transformation by the Suki Project in 1970 indicate that wood resources were readily available and grazing lands were adequate to sustain local livestock, though some large holders sent animals to graze during the harsh dry season with nomadic relatives (see MacDonald et al. 1964; al Tayib 1970).

The Suki Agricultural Project, into which the village was incorporated in 1970, changed all of this. That was precisely its intent. As a development project, the Suki scheme was intended to bolster Sudan's export earnings, to incorporate rural dwellers more firmly into the cash economy as producers and laborers, and to "modernize" the rural sector, among other things. The project, which encompassed 85,000 acres in the vicinity of the village, was predicated on the irrigated cultivation of cotton and groundnuts for the world market, using a crop rotation sequence that precluded the mix of land uses that had sustained people in Howa since its establishment a century before. In clearing and leveling 2,500 acres adjacent to the village for the establishment of 250 farm tenancies for villagers, the Suki Project administration circumscribed the land available for other kinds of 
cultivation, grazing, and forestry. The altered political ecology that resulted, as much as the production requirements of the project itself, deepened Howa's intersections with the cash economy. In limiting grazing lands and drastically reducing wooded areas, the project gradually led to the commodification of formerly free, shared, or commonly held goods such as wood, meat, and ultimately milk. For people with deep and enduring pastoral roots, the last was anathema.

But that was not all. Tenants were expressly forbidden to cultivate sorghum on project lands. In a stroke, people who had been relatively selfsufficient in food production were prevented from growing their staple crop except on the marginal lands left out of the project. As they became contract farmers, they also became purchasers of sorghum. But there was a twist to this common effect of "development." Since independence, much of the patronage and private development in Sudan had gone into the expansion of mechanized sorghum cultivation by large holders, and this had stepped up in the 1970s. By the end of the first decade of the Suki Project, the price of sorghum soared 2,000 percent, and people's vulnerability was palpable. Gone from the landscape were their old earthen storage pits for sorghum, with surpluses from which they might have benefited given these price increases. Instead they faced increasing food insecurity. At the same time, the first wave of structural adjustments hit Sudan, reducing food subsidies and pushing harder on the government to focus on export crops. Food vulnerability led to anger and resistance, and in 1981 the Suki Tenants Union agitated for and won the right to cultivate sorghum in their tenancies, albeit in their groundnut and not their cotton allocation. In the meantime, as pastures deteriorated, many evaded project authorities and let their animals browse on the cotton crop. While the latter strategy of resistance redirected land and labor value to tenant households and away from national coffers and international ministrations, the former traded potential income for food.

The 1970 project was the outcome of and dovetailed with a set of national and international development strategies. Sudan's development has been pegged to cotton export since the establishment of the Gezira Scheme in 1925, which supplied the textile mills of Manchester, England. As the market shifted from Britain to the Soviet Union followed by the United States and elsewhere and the world price fluctuated, Sudan's leaders stuck to cotton above all else, although they also supported irrigation projects for sugar, wheat, and groundnuts and the expansion of the mechanized farm areas of central Sudan for the rain-fed cultivation of sorghum. The Suki Project, which drew on gravity irrigation from the Blue Nile, had been in the works prior to the so-called May Revolution of 1969, when 
Ja'afar Mohamed al Nimeiri came to power in a military coup, but it was expedited so that his administration could demonstrate its commitment to rural development. In the rush, built-in land use conflicts and shoddy work were ignored, which led to production difficulties, greater socioeconomic differentiation than might have been expected, and serious but avoidable environmental degradation that further propelled commodification of formerly free or commonly held goods such as wood, wild fruit, meat, and milk.

\section{A topography of globalization}

The effects of capitalism, imperialism, and state power were everywhere manifest in Howa from 1979 when I first visited. They riddled everyday material social practices, and in the last two decades they have rescripted the relationships between local residents and their social networks, altered their sense of their place in the world (and the world in their place), and changed the grounds, literally, of work and play (Katz 1991a, 1991b, 1998). Needless to say, these transformations produced new contradictions and, with them, political possibilities. These outcomes can be scrutinized through means of a topography that at once expresses and enlivens the operations of globalization while bringing them to bear on material social life. I am going to address three moments of globalization that have produced distinct but connected arenas of transformation and trace some of the gendered political practices they call forth. The three moments, or traces, of globalization I will examine are economic restructuring, "timespace expansion," and Sudan's enduring civil war. In Howa, these moments have prompted distinct, though limited, political responses that I have separated analytically as reworking, resilience, and resistance.

The first trace of globalization concerns economic restructuring. Restructuring builds upon and reroutes the uneven developments that are crucial to capital accumulation (see Smith 1984). Restructuring shifts capital and other resources across many of the fault lines that were produced (and made to appear as natural) in earlier phases of capital accumulation, among them those between the so-called first and third worlds, between differentiated regions, between rural and urban areas, between various economic sectors, and between classes. In Howa, restructuring has come in a number of forms. Particularly relevant are the transnational shifts in capital investment that occurred during the 1960s and 1970s when capital disinvestment in some of the older industrial areas of Europe and the Americas was balanced by reinvestment in agricultural and industrial production in various parts of Africa, Asia, and South and Central America. In 
decolonized Africa, such investments were purportedly intended to further "development" and set the stage for "economic take-off," and, not coincidentally, to tie a growing number of people into the logics and social relations of capitalist production and reproduction.

In the early 1970s, however, the oil shocks and widespread recession in many parts of the industrialized world altered patterns of international investment. In Sudan, newly wealthy Arab countries invested heavily in the development of food production, envisioning Sudan as their "breadbasket." Their aid helped to blunt the edge of the oil shocks, but for a variety of reasons - among them corruption, patronage-fueled "development," and the inflationary effects of increased oil prices - Sudan's economy and balance of payments faltered. By the late 1970s, restructuring had taken the form of brutal sectoral shifts within and between various geographic regions, meted out and monitored by the International Monetary Fund's (IMF's) vicious policies of structural adjustment. Starting in 1978, for instance, Sudan was subjected to IMF policies that, among other things, mandated the removal of food subsidies, insisted on an exportbased economy (the production of export crops at the expense of food crops), and put in place other policies that placed the burden of repayment of Sudan's (soaring) external debt on the backs of its children and poorest people (see Ali 1985; Bradshaw et al. 1993; Walton and Seddon 1994).

At first in Howa, the effects of restructuring were most directly experienced through the Suki Project, a massive state-sponsored and multilaterally funded agricultural development project. Its intent and effect were to transform an area of mixed land use, with minimal cash crop production, into a political ecology geared largely to cash cropping and full incorporation into the national and global economies. Much of the area around the village was cleared and leveled to support the irrigated cultivation of cotton and groundnuts for the world market, while animal husbandry and forestry were relegated to marginal off-project lands. These lands were therefore subjected to a much more intense use than before, straining local political ecologies.

I was particularly interested in what happened to children as subjects and "objects" of social reproduction under these conditions. I wanted to see how these altered political-economic, sociocultural, and political-ecological conditions affected their everyday lives and opportunities, and how in their work, play, and learning children negotiated this shifting terrain to construct themselves as historical subjects and social actors while helping to make a world they might inhabit as adults. I was looking for resistance.

My findings were grim. For instance, because of the nature of cotton 
and groundnut cultivation in the irrigation project, more, not less, family labor was required after the project than before. Moreover, increased land use intensity around the project led to collateral environmental changes that increased the time required for the more distant procurement of wood and the grazing of animals, both largely children's tasks. The pace of commodification and monetization of the economy had also intensified, in part because goods that were formerly held in common or free, such as wood or milk, were becoming more difficult to procure, and in part because a wealth of products from other parts of Sudan or further afield were being introduced into local markets, and a growing number of residents were seduced by them.

These shifts regrooved the particular gendered and otherwise differentiated relations of production and reproduction in Howa, increasing children's labor time and reducing possibilities for attending school. Certain aspects of land tenure in the Suki Project, for instance, helped increase the valences of patriarchy and the power of Howa's men to mobilize the labor of their children and wives. In particular, by initially allocating tenancies in the project to men, except in rare cases, the project administration relied on and enhanced their ability to conscript family labor when, for (perennial) financial reasons, they were not able to hire external labor. The more distant and more time-consuming acquisition of wood fuels and grazing of animals especially affected children because, growing up in Islamic northern Sudan, where women of prime child-bearing age (roughly between puberty and thirty-five years of age) were discouraged from working outside the hosh or houseyards of their extended families, these tasks fell to children. As a result of this gendered dynamic, environmental degradation had a disproportionate effect on children's lives, narrowing their opportunities to acquire a formal education. For similar reasons, rampant commodification also increased children's work time. Child labor provided vital additional cash for their increasingly strapped households to purchase newly commodified or recently introduced goods. Children also procured certain commodified goods such as wild fruit, water, or wood so that their families could either save the expenditure on them or benefit from their sale to others in the village or further afield.

For children coming of age in Howa, restructuring meant the twin ravages of displacement and de-skilling. As the agricultural project transformed the conditions of production and social reproduction, children found themselves reproducing the familiar constellation of agriculture, animal husbandry, and local forestry use, but it was an increasingly untenable political ecology. The project's land tenure arrangements from the outset 
fixed the number of tenancies lower than the number of households in Howa. As the average household included five children and most parents of young adults remained economically active themselves, access to productive land for most young men coming of age was out of the question. Yet few had been able to attend school to prepare for other work possibilities in Howa or in the towns.

That the globalizing impetus borne by the Suki Project was the primary source of these shifts was undeniable but is only part of the story. Safety valves that might in other societies have absorbed the increasing economic pressure were largely unavailable here. Deep-seated corruption and patronage systems filtered the development strategies through powerful social hierarchies, stunting the distribution of resources and access to betterpaying nonagricultural jobs. For example, one of the few young men in the village who had earned a secondary school certificate by the 1990s had not been able to find a job after searching in government offices, private companies, and banks in several nearby towns and the capital area. He was forced to return home and take a teaching job in a neighboring village that paid the equivalent of U.S.\$22 a month, well below subsistence levels even in the countryside. Bemoaning his situation, which included an indefinitely postponed marriage, he said, "No one wants this job, only if you can't find work outside would you take this. Good jobs are available but I don't have strong connections (wasta gowiya); you need recommendations from someone 'from within' ... if you don't know anybody on the inside, you can't get in" (Abdullah 1995).

For girls matters were at once worse and better than for the boys. Less than 5 percent of the girls in Howa between seven and twelve years of age attended school in the early 1980s. Most were too important to the daily work of reproduction, including gathering wood, fetching water, minding children, and assisting with a range of household chores, to be spared by their families for school, especially in a coeducational setting that was frowned upon by many parents and grandparents. In addition to these tasks, girls also participated in farming until they reached puberty, when their participation began to taper off, depending on family wealth. Unlike boys, girls were not taught the skills required to handle the demands of the agricultural cycle or the overall sequencing of seasonal agricultural tasks. Thus, when some boys began to migrate as they reached adulthood, often leaving their sisters to tend to agricultural production, the girls were ill prepared. Girls were well prepared to continue the work of reproduction within their community, but, because displaced young men now found it more difficult to raise a bride-price and start a household, the age of mar- 
riage was increasing, leaving young women to work in their family households much longer than had been customary. Unlike in the past, many of those well past puberty continued to work family fields, thus drawing upon widely shared community knowledge that might otherwise have lain dormant.

Nevertheless, one of the most palpable changes I witnessed in the wake of these shifts in the local and broader political economy was a villagewide mobilization on behalf of schooling girls. In less than a generation, village leaders had deployed the resources of a series of self-help initiatives to build and staff a girls' elementary school, and by 1995 the finishing touches on a coeducational secondary school (with separate classes for girls and boys) were being put in place. The change in a period of less than fifteen years was astonishing; in 1981 only 4 percent of all girls between seven and twelve years old attended school, but by 1995 over 43 percent of girls that age were in school. As Zeineb Dafalla, one of the older women in the village, said when I asked her how things had changed in Howa during that same period, "If you have a pen like that you eat, if you have an axe, you don't" (1995).

Increased schooling for girls was the good news. The paradox is that much of the work that might have been available to them never materialized or dried up, thanks to Sudan's enduring economic stagnation, and this was exacerbated by the withdrawal of many businesses and the near total exodus of nongovernmental organizations (NGOs) from the country as a result of the renewed civil war. This situation seriously constrained the fluidity and creativity of local responses to various economic shifts. But there was a flip side. Poor management, dissipated development schemes, civil war, and international embargo all provoked a crisis of the Sudanese state and economy, and this led to substantial labor migration after the 1970s, particularly among educated men. These shifts created a vacuum in the civil service and in public sector employment generally, which meant burgeoning employment opportunities for educated women. By the mid1990s many joked that Sudan had become a matriarchy. Most of these positions were filled by women from the better-trained urban middle classes, but such contradictory provocations of opportunity might eventually change the shape of employment around Howa as well, especially in areas such as teaching, health care provision, and social services. While there was not yet a culture of women working outside the home in Howa, the selfhelp efforts to expand education for girls along with the women's literacy classes sporadically offered by the social extension services of the agricultural project are inklings of change in local cultural forms and practices 
concerning women's work and roles. Local efforts indicate a particular politics of reworking in the face of some of the devastating shifts associated with restructuring.

Built upon these iterations and effects of restructuring is a reformulation of the time-space of everyday life that reveals another path of globalization. I call this process time-space expansion (pace Harvey 1989). While David Harvey, drawing on Marx, notes that one of the signal effects of advanced capitalism is "the annihilation of space by time" (273), which creates one of the characteristic conditions of postmodernity, time-space compression, I found something quite different in rural Sudan. From the vantage point of capital, the world may be shrinking, but, on the marooned grounds of places such as Howa, it appeared to be getting bigger every day. After a grueling decade and a half of structural adjustments and political upheaval in Sudan, people in Howa survived by maintaining a semblance of the patterns and practices of production that long had sustained them: agriculture, animal husbandry, and forestry. But this was only viable now if carried out over an extended physical arena. The terrain of social production and reproduction had expanded from perhaps five kilometers in 1980 to two hundred kilometers by 1995 , the distance men routinely traveled to participate in the charcoal trade. Time-space expansion also represented a transformation of the old constellation of activities that involved men's long absences from the village. People still farmed (but also worked as agricultural laborers up to a hundred kilometers away), kept animals (by sending them out with relatives to distant pastures), and cut wood (but now in areas of the South targeted for deforestation as part of the northern government's war effort) (see Katz 2000). The more things stayed the same, the more different they were. The old constellation inscribed a new geography and was bolstered by intensified labor migration among village men to various towns in Sudan and to the Gulf States, Libya, and Saudi Arabia, a wholly new source of work since the 1980 s.

While the migrations propped up an increasingly untenable local economy, they also altered men's relationships to one another and to their families. Not only did labor migration force postponement of marriage and child rearing, but it exposed migrants to the cultural and political-economic flows of globalization in ways that were unknown previously. Among other things, these practices gave rise to a kind of rural cosmopolitanism that was dramatically new. What was perhaps most interesting, and certainly most politically repercussive, was how these new political-economic relationships did not undermine earlier political ecologies but rather enabled their endurance despite myriad contradictions and difficulties. Exotic consumer products acquired after a stint of working in Saudi Arabia, for 
instance, were purchased not so much for consumption as for a hedge against debt or calamity. Videocassette recorders (VCRs) were more a means of saving money - much as livestock had been - than machines to play videos. The shift made sense in Howa, which lacked both pastures and electricity.

Time-space expansion embraces, reworks, and plays into the altered geographies of globalization. While people in Howa found it increasingly necessary to expand the space of their economic operations in order to stay afloat and enable the mix of agriculture, animal husbandry, and forestry to endure, the social matrix within which they understood themselves and their economic prospects had changed dramatically within just one generation of the establishment of the project. If in one way the known world expanded for people in Howa, in others their place in it receded as their village was increasingly marginalized. The expanded field of material social practice that characterized Howa by 1995 - what I am calling time-space expansion - tells the twisted tale of "development" and its disintegrations. But, in enabling the endurance of particular geographies of sustenance that served the local population, the new geographies also speak of a politics of resilience.

If restructuring and time-space expansion are the first two traces of globalization, the third encompasses Sudan's enduring legacy of racialized religious enmity between north and south, the residual and still concussive effects of colonization, the discovery of significant oil reserves in southern Sudan, and the rise of Islamic fundamentalism as a political force in Sudan. Separately and in concert, these led to the resumption and intensification of Sudan's civil war in 1983, ending the respite afforded by the Addis Ababa Agreement of 1972 that halted the war that had engulfed Sudan since just prior to independence in 1956. The civil war can be traced to a historical geography of wildly uneven wealth and power stoked for centuries by imperial and domestic rulers, to the violent effects and seething distrusts of a centuries-old Arab slave trade, and to the unequal distribution of resources by successive governments. The war also reflects the destabilizing national and regional boundaries left by the British that tethered Christian and animist southerners to Islamic and Arabicized northerners. Among the more proximate precipitants of the renewed war were the 1979 discovery by Chevron Oil of substantial oil fields in the Bentiu area of southern Sudan coupled with the cynical government decision to construct a refinery in the north, the constant aggravation of enduring racialized inequalities between north and south by the northern-dominated government, and the imposition of Shari'a Law on the non-Islamic south in 1983. The imposition of Islamic law, which included a prohibition on alcohol so 
complete that it covered the lightly fermented grain beverages that were a nutritious dietary staple in much of the south, was part of Nimeiri's last desperate attempt to stay in power after fourteen years of political oscillation by pandering to the increasingly powerful National Islamic Front. The renewed civil war, waged as a jibad by the Islamicist government that came to power in 1989, has brought death to over two million people, along with unimaginable suffering, starvation, forced displacement, and extensive destruction of property in the south. And it has made Sudan a pariah within the international community and hemorrhaged the already bare national treasury.

The effects are no longer contained or containable in the south. By 1995, the government of Sudan was spending over a million dollars a day on the war while almost all sources of foreign investment and donorship had dried up. Apart from direct relief and emergency assistance related to the war, most NGOs had halted their operations in Sudan. The only exceptions were funding from the so-called hard-line Islamic fundamentalist states and from private Islamicist organizations. In addition, the government of Brigadier Omer al Beshir has been vigorous in imposing and collecting taxes throughout the country. Its energy in this regard has contributed to widespread immiseration and was the source of constant complaint in Howa. Residents were taxed on various forms of property including their mud dwellings, livestock, and other property, and they were charged for permits to engage in such basic income-producing activities as cutting firewood, producing charcoal, or harvesting crops. People who attempted to evade taxation in Howa, which is in the north but only a few hundred kilometers from the fighting in the south, had their allocations from the government sugar cooperative confiscated and sold to raise the requisite funds. Considering that two schools, a mosque, a well, and stand pipes to distribute the well water were built with sugar cooperative funds in just under two decades, the sums under consideration were not inconsiderable.

More serious was the looming human toll of the war. In 1995, the first "people's militia" in the village was formed under the aegis of the National Islamic Front government. Young men and teenage boys were conscripted into a military training program for the People's Defense Forces that was carried out daily in the village for several months to instill discipline, encourage support for the authoritarian, right-wing, Islamicist government, and prepare troops for the depleted armed forces. While participation in the militia was putatively voluntary, those not attending were barred from government employment or refused job advancement if they were already government employees. The government was the key source of what few 
employment possibilities existed for disenfranchised rural people. Emigration was the other hope, and it was widely known that the only way to have any chance of receiving a permit to travel or work abroad was to join the "people's militia" and serve the requisite number of years depending upon education level.

The government forced young men's hands, but it had no guns to thrust into them. In the daily militia drills in Howa, sticks were used instead. The spectacle was depressing for all concerned. Every young man I spoke to said he participated because he felt coerced, and every mother of a participating son worried that the conscriptions would not stop there. Indeed, several young men had already joined the army to fight the war against the south. Because the war had been declared a jibad, anyone killed carrying out his duty would die a martyr and gain entry to Paradise. The promise of Paradise - eternal life in a lush garden surrounded by gorgeous women ready to meet every need - could not have been more tantalizing for young men coming of age in a dusty village where their prospects for meaningful work seemed to recede daily, and with them any hope of marriage. Without steady work, young men could not dream of marriage (and with it ready access to sanctioned sex with women). Like everything else in Sudan, bride-prices had been subject to roaring inflation since the 1980s and were edged further upward as they became increasingly inflected by globalized cosmopolitan tastes. The government employed shrewd cynicism indeed by simultaneously prosecuting the war as a jibad and purveying gendered and sexualized images of Paradise to such marginalized and anxious young men.

But the circumstances of war had engendered a political response - this time one of resistance overlaid on reworking and resilience. While young men increasingly attempted to evade military service by emigrating to the Gulf States and Saudi Arabia (usually illegally), or tried to remain outside the disciplinary circuits sustained by the Sudanese state (though this was increasingly difficult to accomplish), and people, as ever, tried to avoid taxation, women in Sudan were beginning to protest the war directly. Particularly in urban areas, women kept their sons from attending their final examinations in secondary school because that was where conscription took place-no diploma, no draft notice. Desperate enough to compromise their children's futures in order possibly to save their lives, women also took to the streets in protest. Public demonstrations against the $\mathrm{Na}$ tional Islamic Front government are extremely risky and rare, and several women were arrested in Khartoum in December 1997 for publicly protesting the war. The parallel with mothers' protests elsewhere, such as the Asociación Madres de Plaza de Mayo in Argentina, Mothers for Peace in 
Zagreb, or the international Women Strike for Peace, founded in 1961 to protest nuclear testing and in particular its effects on children, should be obvious.

\section{Constructing countertopographies}

If topography is traditionally seen as embodying landscapes along with their description and delineation, I have chosen here to mobilize topography as a distinct research method. To do a topography is to carry out a detailed examination of some part of the material world, defined at any scale from the body to the global, in order to understand its salient features and their mutual and broader relationships. Because they routinely incorporate both "natural" and social features of a landscape, topographies embed a notion of process, of places made and nature produced. If "history is lifeless without topography," so, too, are topographies without history. Not only can a sense of sedimented process be read off the land itself, but producing topographies necessarily situates places in their broader context and in relation to other areas or geographic scales, offering a means of understanding structure and process. Indeed my project here is driven by the notion that producing a critical topography makes it possible to excavate the layers of process that produce particular places and to see their intersections with material social practices at other scales of analysis. Revealing the embeddedness of these practices in place and space in turn invites the vivid revelation of social and political difference and inequality.

The topography here was intended to produce a thick historical geography of Howa, making clear that it is not simply globalization that is important but also its encounter with existing social relations and material social practices in particular places. In Sudan the material social practices associated with globalizing capitalist relations of production and reproduction intersected with volatile political circumstances, disintegrating economic conditions, and a deeply troubled historical geography of racialized religious and ethnic difference to make them all worse. Each of these threads of local globalizations can be seen in the landscape, and doing a topography brings them into sharp relief to expose their tensions, contradictions, and affiliations. In the topography here, for instance, we can see how globalization has provoked, undermined, and reworked the sedimented social relations of production and reproduction in Howa along with many of the cultural forms and practices of everyday life to produce a precarious political ecology for its population. I have traced just three strands of this process, economic restructuring, time-space expansion, and Sudan's civil war, but these and other processes can be followed to other places - within and 
beyond Sudan's borders - to produce analytic "contour lines" situating distinct locales in relation to particular social practices.

Topography is resolutely material. But there are productive metaphorical entailments of the idea as well, and these are also at the heart of why I have done a topography of globalization in Howa. Topography is associated not just with the description of place but also with measurements of elevation, distance, and other structural attributes that enable the examination of relationships across spaces and between places. The material social practices associated with globalization work in interconnection, such as when capital, labor, or cultural products move from one place to another, but they work iteratively as well: the effects of capitalism's globalizing imperative are experienced commonly across very different locales, and understanding these connections is crucial if they are to be challenged effectively. Topographies provide the ground-literally and figuratively - for developing a critique of the social relations sedimented into space and for scrutinizing the material social practices at all geographic scales through which place is produced.

If what I have produced here is a critical topography intent on showing certain traces of globalization on particular grounds, how can the significance of these forms and practices be made translocal and connected to other specific topographies affected by global processes in analogous ways? Accomplishing such a move involves the construction of a countertopography. And here I want to draw on a more metaphorical sense of topography that refers to a central aspect of most topographical maps - the contour line. Contour lines are lines of constant elevation, connecting places at precisely the same altitude to reveal a terrain's three-dimensional shape. I want to imagine a politics that maintains the distinctness of a place while recognizing that it is connected analytically to other places along contour lines that represent not elevation but particular relations to a process (e.g., globalizing capitalist relations of production). This offers a multifaceted way of theorizing the connectedness of vastly different places made artifactually discrete by virtue of history and geography but which also reproduce themselves differently amidst the common political-economic and sociocultural processes they experience. This notion of topography involves a particular precision and specificity that connects distant places and in so doing enables the inference of connection in uncharted places in between. As with contour lines, the measurements of elevation at select sites enable a line to be drawn without measuring every spot on earth. Such connections are precise analytic relationships, not homogenizations. Not all places affected by capital's global ambition are affected the same way, and not all issues matter equally everywhere. By constructing precise topographies at 
a range of scales from the local to the regional and beyond, we can analyze a particular issue - say de-skilling - in and across place, mapping sites connected along this contour line.

The larger intent is to produce countertopographies that link different places analytically and thereby enhance struggles in the name of common interests. In many ways this builds an oppositional politics on the basis of situated knowledges. Doing topographies therefore builds upon feminist and Marxist insights concerning exploitation, oppression, and power (see Hartsock 1984; Haraway 1988; Mohanty 1988). If situated knowledges suggest local particularities of the relations of production and reproduction, their conscious apprehension in a globalized and multiply differentiated world offers fertile political connections across space and scale that have the fluidity to match and confront the deft global mobility of capitalist investment and disinvestment successfully. But the notion of situated knowledge itself only gets us partway there.

Situated knowledge assumes knowledge at a single point, the knowing subject, and the particularity of that subject's vision is both its strength and its downfall. If the brilliance of the idea of situated knowledge was in making clear that all seeing, all knowing was from somewhere, and that that somewhere was socially constituted, allowing for and occluding particular insights, the implication of sites underlying knowledge has produced other problems. First, although situatedness may imply a locale, it is most often attributed to a mobile and multiply constituted subject, or what has become known as a subject-position (see Henriques et al. 1984). In any topographic mapping, however, a subject's position in the landscape is a point, and therefore a space of zero dimensions. Thus the language of site and situatedness has tended to facilitate a collapse of dimensionality rather than its opposite. It has therefore proven difficult to get beyond the various cul-de-sacs of identification, productive notions of intersectionality, mobile subjectivity, and multiple identities notwithstanding (see Trinh 1989; Fuss 1991; Crenshaw 1995). Second, while "situated" alludes to somewhere, it specifies no place in particular. Situatedness suggests location in abstract relation to others but not any specific geography, leading to a politics of "sites" and "spaces" from which materiality is largely evacuated. While the imaginative abstraction of "sites" has helped in conceiving new political alliances or strategies, a process I have participated in myself, ignoring the difference that space makes diminishes those political responses by avoiding the ways specific historical geographies embody and help reproduce particular social relations of power and production. ${ }^{1}$ Finally, situatedness is si-

${ }^{1}$ See Anzaldúa 1987; Trinh 1990; Katz 1992; and Bondi 1993. 
multaneously universal-everything is situated-and specific - to the point of being zero dimensional. The politics of extension and translation, from the site (point) to the global, is too easily assumed in the insistence on situatedness, when, of course, that is what has to be explained.

Doing topography, by contrast, already assumes the historical examination of social process in three-dimensional space. It takes for granted that space is both the bearer and reinforcer of social relations, and that if these relations are to be changed so too must their material grounds. Topographies are a means to elucidate the intersections of these processes with others elsewhere and thereby inspire a different kind of politics, one in which crossing space and "jumping scale" are obligatory rather than overlooked (see Smith 1992; Marston 2000). This grounded but translocal politics offers at the very least the possibility of countering the ways that the maneuvers of globalized capitalism exacerbate and build upon gendered, racialized, nationalist, and class axes of oppression and inequality in different historical geographies. What politics might work the contours connecting carceral California, sweatshop New York, maquiladora Mexico, and structurally adjusted Howa, and back again? These are the kinds of questions that topographies encourage us to ask. The prospects are tantalizing and the political stakes great.

In previous work (Katz 1998), I have traced one such line, from Howa to Harlem and back again. I wanted to understand the displacement and de-skilling of young people in the wake of the redlining and disinvestment in their communities. For example, by examining cuts in funds for public housing, public open space, health care, and social welfare benefits and the skewed distribution of funds for education in New York City, I have drawn comparisons between New York City and Howa in the means by which social reproduction was secured. I have compared disinvestments in social reproduction in working-class New York with the lack of public investment in social reproduction in Howa. The former were spurred by waves of economic restructuring that shifted many manufacturing jobs elsewhere, while the latter resulted from the "development" policies pursued by the Sudanese state (in conjunction with international financial institutions) that undermined the traditional means of production and of reproducing local relations in Howa. It seemed to me that in both places, large segments of the generation currently coming of age were being derailed to a marginalized zone in which there were few guarantees for sustained-let alone meaningful - work as adults. In subsequent years, large numbers of this "excessed" population appear to have been "warehoused" as a matter of state policy, as we see in prisons in the United States and in the army or people's militias in the case of Sudan. Nevertheless, in both settings I have 
found remarkable resilience at the community level and a tendency for people to organize to rework the conditions confronting them if not actually to resist them outright. I think of the remarkable increase in support for formal education for girls and boys in Howa in just a single generation and compare that with block-by-block efforts by neighborhood residents in New York to reject crack cocaine and hound its purveyors away. The numbers of children in primary school in Howa more than doubled in less than fifteen years, while recent reports in New York indicate equally dramatic reductions in crack use by young people over a similar period.

Whereas I originally understood the comparison between the two cases more sequentially as an examination of the kinds of displacements children can suffer in the transition from an agricultural to an industrial economy and from an industrial to a postindustrial economy, the perspective offered by doing a topographical analysis affords a more productive and spatialized understanding of the problems. Not only does this kind of analysis reveal the simultaneity of different kinds of disruptions but, making good on John Berger's brilliant insight that it is now "space not time that hides consequences from us," it also reveals the intertwined consequences of globalizing capitalist production in ways that demand a different kind of politics (1974, 40; see Soja 1989). My argument is that if the disruption of social reproduction in Howa and Harlem are two effects of a common set of processes, and I think they are, then any effective politics challenging a capital-inspired globalization must have similar global sensitivities, even as its grounds are necessarily local. This is different from a "place-based" politics. It is not merely about one locale or another, nor is it a matter of just building coalitions between such diverse places, vital as that is. Precisely because globalization is such an abstraction, albeit with varying forms, struggles against global capital have to mobilize equivalent, alternative abstractions. Built on the critical triangulation of local topographies, countertopographies provide exactly these kinds of abstractions interwoven with local specificities and the impulse for insurgent change.

\section{Environmental Psychology}

City University of New York

\section{References}

Abdullah, Ismail [pseud.]. 1995. Interview by author. Tape recording. Howa [pseud.], Sudan, July 9.

Ali, Ali Abdel Gadir, ed. 1985. The Sudan Economy in Disarray: Essays on the Crisis. Khartoum: Ali Abdel Gadir Ali; London: Ithaca. 
Anzaldúa, Gloria. 1987. Borderlands/La Frontera: The New Mestiza. San Francisco: Spinsters/Aunt Lute.

Berger, John. 1974. The Look of Things. New York: Viking.

Bondi, Liz. 1993. "Locating Identity Politics." In Place and the Politics of Identity, ed. Michael Keith and Steve Pile, 84-101. London and New York: Routledge.

Bradshaw, York W., Rita Noonan, Laura Gash, and Claudia Buchman Sershen. 1993. "Borrowing against the Future: Children and Third World Indebtedness.” Social Forces 71(3):629-56.

Burton, John Hill. 1864. The Scot Abroad. Edinburgh: Blackwood.

Crenshaw, Kimberlé W. 1995. "Mapping the Margins: Intersectionality, Identity Politics, and Violence against Women of Color.” In Critical Race Theory: The Key Writings That Formed the Mopement, ed. Kimberlé Crenshaw, Neil Gotanda, Gary Peller, and Kendall Thomas, 357-83. New York: New Press.

Dafalla, Zeineb. 1995. Interview by author. Howa [pseud.], Sudan, July 5.

Fuller, Thomas. 1642. The Holy State. The Profane State. Cambridge: [John Williams].

Fuss, Diana, ed. 1991. Inside/Out: Lesbian Theories, Gay Theories. New York and London: Routledge.

Grewal, Inderpal, and Caren Kaplan, eds. 1994. Scattered Hegemonies: Postmodernity and Transnational Feminist Practices. Minneapolis: University of Minnesota Press.

Haraway, Donna J. 1988. "Situated Knowledges: The Science Question in Feminism as a Site of Discourse on the Privilege of Partial Perspective." Feminist Studies 14(3):575-99.

Hartsock, Nancy. 1984. Money, Sex, and Power: Toward a Feminist Historical Materialism. Boston: Northeastern University Press.

Harvey, David. 1989. The Condition of Postmodernity. Oxford: Blackwell.

Henriques, Julian, Wendy Holloway, Cathy Urwin, Couze Venn, and Valerie Walkerdine. 1984. Changing the Subject: Psychology, Social Regulation, and Subjectivity. London and New York: Methuen.

Katz, Cindi. 1991a. "An Agricultural Project Comes to Town: Consequences of an Encounter in Sudan.” Social Text 28:31-38.

- 1991b. "Sow What You Know: The Struggle for Social Reproduction in Rural Sudan." Annals of the Association of American Geographers 81(3):488-514. 1992. "All the World Is Staged: Intellectuals and the Projects of Ethnography." Environment and Planning D: Society and Space 10(5):495-510.

- 1998. "Disintegrating Developments: Global Economic Restructuring and the Eroding Ecologies of Youth.” In Cool Places: Geographies of Youth Cultures, ed. Tracy Skelton and Gill Valentine, 130-44. London: Routledge.

- 2000. "Fueling War: A Political-Ecology of Poverty and Deforestation in Sudan." In Producing Nature and Poverty in Africa, ed. Vigdis Broch-Due and Richard A. Schroeder, 321-39. Stockholm: Nordiska Africainstitutet and Transaction Press.

MacDonald, Sir M., and Partners. 1964. Roseires Soil Survey, Report 9: Dinder-Blue 
Nile Gezira Sennar to Confluence, Semi-Detailed Soil Survey and Land Classification. London: Hunting Technical Services.

Marston, Sallie. 2000. “The Social Construction of Scale." Progress in Human Geography 24(2):219-42.

Mitchell, Katharyne. 1997. "Different Diasporas and the Hype of Hybridity." Environment and Planning D: Society and Space 15(5):533-53.

Mohanty, Chandra Talpade. 1988. "Feminist Encounters: Locating the Politics of Experience." Copyright 1 (Fall): 30-44.

Oxford English Dictionary. 1971. Oxford: Oxford University Press.

Smith, Neil. 1984. Uneven Development: Nature, Capital and the Production of Space. Oxford: Blackwell.

1992. "Contours of a Spatialized Politics: Homeless Vehicles and the Production of Geographic Scale.” Social Text 33:54-81.

Soja, Edward W. 1989. Postmodern Geographies: The Reassertion of Space in Critical Social Theory. London and New York: Verso.

al Tayib, Gelal al-Din. 1970. The Southeastern Funj Area: A Geographical Survey. Funj Project Paper no. 1. Khartoum: Khartoum University, Sudan Research Unit.

Trinh T. Minh-ha. 1989. Women, Native, Other: Writing Postcoloniality and Feminism. Bloomington and Indianapolis: Indiana University Press.

1990. "Cotton and Iron." In Out There: Marginalization and Contemporary Cultures, ed. Russell Ferguson, Martha Gever, Trinh T. Minh-ha, and Cornel West, 327-36. New York: New Museum of Contemporary Art; Cambridge, Mass.: MIT Press.

Trouillot, Michel-Rolph. 1996. "Theorizing a Global Perspective: A Conversation with Michel-Rolph Trouillot." Crosscurrents in Culture, Power and History: A Newsletter of the Institute for Global Studies in Culture, Power and History, Johns Hopkins University 4(1): 1-4.

Walton, John, and David Seddon. 1994. Free Markets and Food Riots: The Politics of Global Adjustment. Oxford: Blackwell. 